\title{
GUIDANCE AND COUNSELING IN ELEMENTARY SCHOOL
}

\section{Risma Dina*, Muh Farozin \\ *Correspondent Author}

Risma Dina

Universitas Negeri Yogyakarta

Jalan Colombo Yogyakarta Nomor 1, Karang Malang, Sleman Yogyakarta, Indonesia

Email: rismadina817@gmail.com

Muh Farozin

Universitas Negeri Yogyakarta

Jalan Colombo Yogyakarta Nomor 1,

Karang Malang, Sleman Yogyakarta, Indonesia

Email: farozin@uny.ac.id

Page

1-7

\begin{abstract}
The study aimed to develop guidance and counseling programs in elementary schools. To this end, Borg and Gall's research and development was applied. Expert judgment was carried out by 2 competent experts in the field of guidance and counseling and 3 classroom teachers as practitioners in the field of guidance and counseling. Thed data were collected using expert validation questionnaires, practitioner validation questionnaires, and focus group discussion guidelines. The data were analayzed quantitatively. Based on the results of expert validation, the developed product was categorized as good (average score of $86.8 \%$ ). According to the practitioners, the developed product was categorized as good (average score of 91.62\%). It can be concluded that the guidance and counseling program in elementary schools was good and feasible to be implemented after being revised. The results of the study can be used as a reference for elementary school teachers or visiting counselor in carrying out guidance and counseling services in elementary schools.

Keywords: visiting counselor, guidance and counseling, elementary school
\end{abstract}

\section{INTRODUCTION}

Education plays an important role in improving the students' self-quality, especially developing the potential of students in elementary school. Efforts to achieve educational goals are inseparable from the role of all school components. They are important to help students achieve optimal self-development. Optimal development is dynamic conditions characterized by the readiness and ability of students to perform self-improvement so that they become fully functional individuals in their environment (Kartadinata, 2011).

The research conducted by Virani, Riastini and Suarjana (2016) on the description of social attitudes in fourth-grade students of Penarukan State Elementary School, Buleleng District, Buleleng Regency showed the social attitudes of students in disciplinary aspects includes failure to wear complete and neat uniform $(10 \%)$, students lateness and neglecting the homework ( $32 \%)$, and politeness issue, where students speak harshly to others(12\%). Furthermore, the self- 


\section{2 |PSIKOPEDAGOGIA}

JURNAL BIMBINGAN DAN KONSELING

Vol.9, No.1, June 2020

confidence aspect is still categorized as sufficient, which is indicated by the lack of courage of students appearing in front of the class, reticence in expressing opinions, and reticence in working on assignments or questions on the board. These findings are irony, considering that there are still many problems experienced by students in aspects of their development. Therefore, guidance and counseling role is expected to help students solve such problems.

Guidance and development counseling means that outwardly individuals move their individual personalities sequentially and positively towards self-development. This shows that each student has unique characteristics that distinguish him from other students, besides that the potential of students is an asset that is valuable to society and for the future (Karwowski, 2010; Myrick, 2011; Puspitasari, 2018; Gralewski, 2019). Guidance and counseling have a role in providing support for achieving personality maturity, social skills, academic abilities, and leading to the formation of career maturity that can be useful in the future (Rahman, 2009).

As the guidance and counseling pracritioner at school, school counselor must participate as an integral part of the school's mission and function by supporting each student to be a successful student, and motivating them (Lam \& Hui, 2010; Barna \& Brott, 2011; Stone \& Dahir, 2015) School cousnelors must be able to collaborate with all existing parties both with parents of students, community and other supporting professional services as part of supporting counseling and counseling services at schools (Jensen, 2008).

The fact shows that guidance and counseling in elementary school level faces a range of barriers. Barus (2011) points out some of those problems as follows: (1) the absence of guidance and counseling teachers in primary schools, (2) lack of ability, time and facilities to develop programs, (3) misperceptions about guidance and counseling, (4) unavailability of easy, practical program model to guide classroom teachers designing their own guidance and counseling program in elementary schools, (5) the absence of classical guidance service implementation facilities that contain guidance materials and are equipped with practical, ready-to-use and easy presentation media used by class teachers.

The absence of school counselor is one of the problems found in elementary schools. In elementary school level, classroom teacher also plays the role of a counselor in order to develop students' potential. Elementary school teachers are responsible to develop not only the cognitive and skill of their students, but also their students' personal, social, academic, and career aspects. In this regard, classroom teacher are demanded to understand the concept of guidance and counseling. Classroom teachers care expected to provide an effective and efficient guidance and counseling services in elementary school guidance and counseling services. Since the classroom teachers have plenty of time with their students, it is assumed that they would understand how to develop students' potential.

The study aims to develop guidance and counseling programs for elementary school level, a Guidance and counseling services in elementary schools that are integrated into the learning process. Guidance and counseling services in elementary schools have a strategic role in preparing the students character and self-development in elementary schools. The results of the study can be used as a reference for elementary school teachers or visiting counsellor in carrying out guidance and counseling in elementary schools.

\section{METHODOLOGY}

The present study applied Borg and Gall's research and development method. Expert judgment was carried out by 2 competent experts in the field of guidance and counseling and 3 classroom teachers as practitioners in the field of guidance and counseling. Thed data were collected using expert validation questionnaires, practitioner validation questionnaires, and focus group discussion guidelines. The data were analayzed quantitatively using categorization. 


\section{RESULT AND DISCUSSION}

Based on quantitative data analysis, expert judgment on guidance and counseling programs received an average rating of $89.2 \%$, which means the program is categorized as good and worthy of being implemented. The result shows that development of a guidance and counseling program is very important to support the achievement school vision and mission. It is necessary to have a guidance and counseling program in order to assist classroom teachers in providing more structured guidance and counseling services. It held as one of the ways to support the achievement of the mission vision goals in schools and to help students in elementary schools achieve optimal development.

The results of expert validation were $86.8 \%$ (good category), and the results of practitioner validation received an average rating of $91.62 \%$. (good category). Details of the description of the results of the expert validation assessment and practitioners' validation of the guidance and counseling program in elementary schools can be seen in following figure 1.

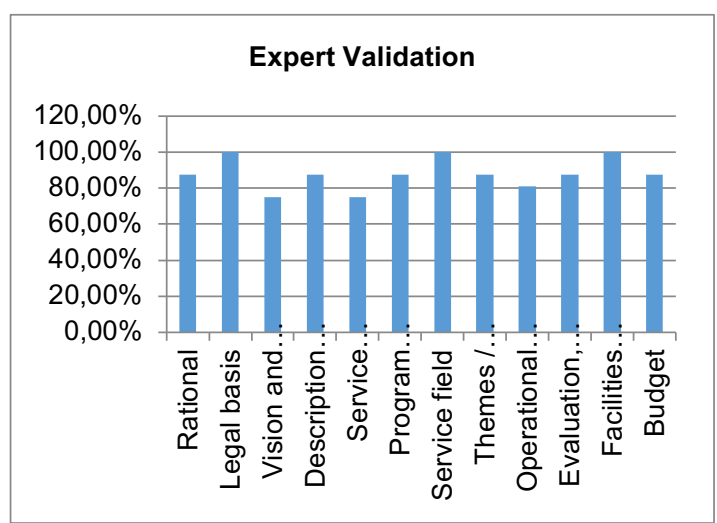

Figure 1:

Expert validation assessment of guidance and counseling programs in elementary schools

Rational assessment gets an average rating of $87.5 \%$, the legal basis gets an average rating of $100 \%$, vision and mission gets an average rating of $75 \%$, description of needs gets an average rating of $87.5 \%$, the service purpose of getting an average valuation of $75 \%$, program components get an average rating of $87.5 \%$, service field sectors get an average rating of $100 \%$, themes / topics get an average rating of $81.2 \%$, operational plans get an average rating of $87.5 \%$, evaluation, reporting and follow-up get an average rating of $87.5 \%$, facilities and infrastructure get an average rating of $100 \%$, the budget gets an average rating of $87.5 \%$.

Guidance and development counseling means that outwardly individuals move their individual personalities sequentially and positively towards self-development. Figure 2 shows that each student has unique characteristics between one another. In addition, students' potential is a valuable asset for the sociaty and the future. It could be optimized when the school manage to facilitate proper guidance and counseling program.

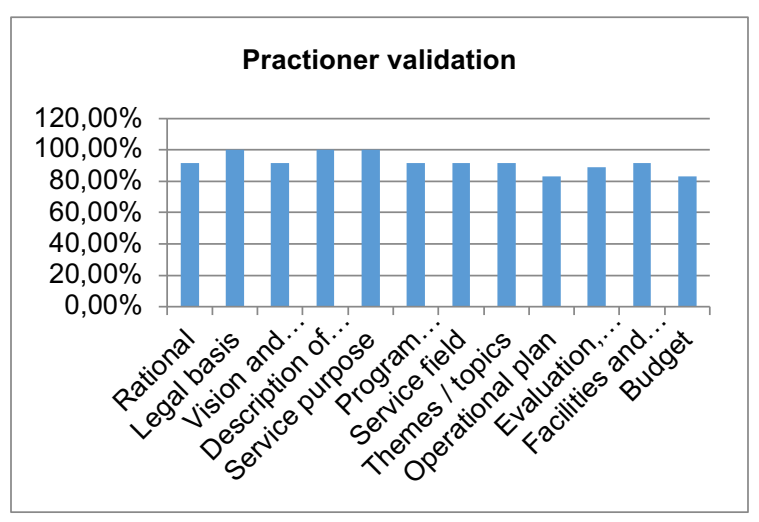

Figure 2:

Practitioner validation assessment of guidance and counseling programs in elementary schools

Based on quantitative data analysis, practitioner judgment on guidance and counseling programs received an average rating. It is mean that practitioner also look forward for how development of a guidance and counseling program are good for held in elementary schools. Guidance and counseling programs provide effective benefits for students, parents, and teachers to achieve optimal development of the school.

The achievement of the objectives of guidance and counseling services in elementary schools are reflected in a series of activities that are arranged systematically, structured, and written in a program. The programs are an integral part of the education 
system, designed to help students develop and have a deep understanding of themselves.

As the implementers of guidance and counseling services in schools fully guidance and counseling teachers in schools must participate as an integral part of the school's mission and function, support each student to be a successful student, and enable their future success (Stone \& Dahir, 2015). It is showed in the implementation of guidance and counseling at the Sungai Miai 5 Elementary School in Banjarmasin. It was carried out based on the results of understanding of students. Implementation of guidance and counseling at Miai River Elementary School is integrated with the learning process. The change is in the form of increasing teachers' insight into training materials, namely, urgency, scope, procedures, and strategies for guidance and counseling activities. Another change is that the teachers have been able to make administrative planning, implementation, assessment, and administration reporting of guidance and counseling activities well.

This guidance and counseling program is expected to be a reference for classroom teachers in providing guidance and counseling services. The annual program of guidance and counseling can help classroom teachers in an effort to help students achieve optimal development both in the personal, social, learning and career fields.

Optimizing the performance of classroom teachers in the implementation of guidance and counseling should be further enhanced so that the annual program goals of guidance and counseling can be achieved properly. The research conducted by Marzuki (2017), the results of the study showed that there was a positive change in the teacher guidance and counseling activities at the school after the training was held. The change is in the form of increasing teachers' insight into training materials, namely, urgency, scope, procedures, and strategies for guidance and counseling activities. Another change is that the teachers have been able to make administrative planning, implementation, assessment, and administration reporting of guidance and counseling activities well.

The achievement of the objectives of guidance and counseling services in elementary schools should be reflected in a series of activities arranged systematically, structured, and written in a program. Counseling and guidance programs are an integral part of the education system, designed to help students develop and have a deep understanding of themselves. The implementation of the program should be oriented towards meeting the developmental needs of students in elementary schools. The guidance and counseling program is expected to accommodate all the guidance and counseling activities that will be provided to students. So from that the formula for the purpose of guidance and counseling services must be based on the results of the analysis of the development needs of students (Pordelan, et. al., 2018).

Research conducted by Afande (2015) shows that guidance and counseling programs provide effective benefits for students, parents, and teachers. Furthermore, research conducted by Latifa (2017) on the developmental aspects of elementary school children: problems and their development. The results of the study show that the developmental aspects have a significant influence on the teaching and learning process in the classroom. This study shows that the developmental aspects of students are very important to note because the stages of development are important and even fundamental for the success of the development of students to the next stage. This further emphasizes the importance of the developmental aspects of students to be considered because it will greatly affect the development of students to the next stage. The process of developing guidance and counseling programs requires a carefully designed and carefully planned plan based on the needs and environment of students (Lunenburg, 2010; Gysbers \& Henderson, 2014). The preparation of guidance and counseling programs in schools should be started from assessment activities, where the assessment activities are very important as an 
activity to identify aspects that are used as input for the preparation of the guidance and counseling program. Assessment is the foundation activity for accountable program development (Carman, 2010).

Research conducted by Batubara and Ariani (2018) showed that the implementation of guidance and counseling at the Sungai Miai 5 Elementary School in Banjarmasin was carried out based on the results of understanding of students and is integrated with the learning process. The results of the interview also showed that the implementation of guidance and counseling at the Sungai Miai 5 Elementary School in Banjarmasin was not well programmed. Because, some teachers do not understand the implementation of school guidance and counseling.

Compilation of a comprehensive guidance and counseling program must be able to understand the design and how to implement it. Dollarhide and Saginak (2011) emphasizes that to be comprehensive, guidance and counseling programs must have the following characteristics: (1) holistic, (2) systemic, (3) balanced, proactive, (4) integrated in the school curriculum, and (5) reflection. According to the American School Counseling Association (2012) the components of the guidance and counseling program consist of: (1) foundation, (2) delivery system, (3) accountability, (4) and management system.

Furthermore, there are five basic premises in managing and developing guidance and counseling programs in schools, as follows (Gysbers \& Henderson, 2014; Cinotti, 2014; Sink, et al, 2017). (1) guidance and counseling programs have the same characteristics and become part of the education program in schools, (2) guidance and counseling programs are developmental and comprehensive, (3) guidance and counseling programs involving collaboration between staff, (4) guidance programs and counseling was developed through a series of systematic processes from planning, design, implementation, evaluation, and sustainability, (5) guidance and counseling programs supported by strong leadership.
The development of a guidance and counseling program is important to support achievement of the school vision and mission The structure of the development of a comprehensive guidance and counseling program refers to the development of programs from Gysbers which have also been explained in the Operational Guidelines for Guidance and Counseling in Primary Schools which consist of. : (1) rational, (2) legal basis, (3) vision, mission, (4) description of needs, (5) formulation of objectives, (6) program components, (7) service fields, (8) theme / topic development, (9) activity / operational plans, (10) evaluation, reporting and followup, (11) facilities and infrastructure, (12) budget (Gysbers \& Henderson, 2014; Dimmit \& Wilkerson, 2012).

As described earlier, it is necessary to have a guidance and counseling program in order to assist classroom teachers in providing more structured guidance and counseling services. The guidance and counseling program can be used as a reference in the implementation of good guidance and counseling. The guidance and counseling program is held as one of the ways to support the achievement of the mission vision goals in schools and to help students in elementary schools achieve optimal development.

\section{CONSLUSION}

Guidance and counseling in elementary school plays a strategic role in driving students' character and self-development. Expert and practitoner validations indicated that the developed program in this study is feasible to be implemented by visiting counselor or classroom teachers in elementary school.

\section{REFERENCES}

Afande, O. (2015). Effects of guidance and counseling on pupils in public primary schools in makadara primary schools in makadara division of nairobi province. Research on Humanities and Social Sciences, 5, 63-77.

Association, A. S. C. (2012). ASCA national model: a framework for school 


\section{6 |PSIKOPEDAGOGIA}

JURNAL BIMBINGAN DAN KONSELING

Vol.9, No.1, June 2020

counseling programs. American School Counselor Association.

Barna, J. S., \& Brott, P. E. (2011). How important is personal/social development to academic achievement? the elementary school counselor's perspective. Professional school counseling, 14(3).

Batubara, H. H., \& Ariani, D. N. (2018). Penyelenggaraan bimbingan dan konseling di sekolah dasar. jurnal pendidika. Teori, Penelitian, Dan Pengembangan, 3(4), 447-452.

Brown, D., \& Trusty, J. (2005). Designing and leading comprehensive school counseling programs: promoting student competence and meeting student needs. Brooks/Cole Publishing Company.

Carman, J. G. (2010). The accountability movement: what's wrong with this theory of change?. Nonprofit and Voluntary Sector Quarterly, 39(2), 256-274.

Cinotti, D. (2014). Competing professional identity models in school counseling: a historical perspective and commentary. Professional Counselor, 4(5), 417-425.

Dimmitt, C., \& Wilkerson, B. (2012). Comprehensive school counseling in rhode island: access to services and student outcomes. Professional School Counseling, 16(2), $2156759 \times 0001600205$.

Dollarhide, C. T., \& Saginak, K. A. (2011). Comprehensive school counseling programs: K-12 delivery systems in action. Pearson Higher Ed.

Gralewski, J. (2019). Teachers' beliefs about creative students' characteristics: A qualitative study. Thinking Skills and Creativity, 31, 138-155.

Gysbers, N. C., \& Henderson, P. (2014). Developing and managing your school guidance and counseling program. John Wiley \& Sons.

Jensen, R. L. (2008). Utah model for comprehensive counseling and guidance: K-12 programs. USA: Utah State Office Of Education.

Kartadinata, S. (2011). Menguak tabir bimbingan dan konseling sebagai upaya pedagogis. Bandung: UPI Press.

Karwowski, M. (2010). Are creative students really welcome in the classrooms? Implicit theories of "good" and "creative" student'personality among polish teachers. Procedia-Social and Behavioral Sciences, 2(2), 12331237.

Latifah, U. (2017). Aspek perkembangan pada anak sekolah dasar: masalah dan perkembangannya. Academica: Journal of Multidisciplinary Studies, 1(2), 185-196.

Lam, S. K., \& Hui, E. K. (2010). Factors affecting the involvement of teachers in guidance and counselling as a whole-school approach. British Journal of Guidance \& Counselling, 38(2), 219-234.

Lunenburg, F. C. (2010). School guidance and counseling services. Schooling, 1(1), 1-9.

Marzuki, I. (2017). Optimalisasi Peran Guru Kelas Sebagai Konselor Siswa di Sekolah Dasar. JTIEE (Journal of Teaching in Elementary Education), 1(1), 37-46.

Myrick, R. D. (1987). Developmental guidance and counseling: A practical approach. ERIC.

Pordelan, N., Sadeghi, A., Abedi, M. R., \& Kaedi, M. (2018). How online career counseling changes career development: A life design paradigm. Education and Information Technologies, 23(6), 2655-2672.

Puspitasari, L., In'am, A., \& Syaifuddin, M. (2018). Analysis of students' creative thinking in solving arithmetic problems. International Electronic Journal of Mathematics Education, 14(1), 49-60.

Rahman, F. (2009). Bimbingan dan konseling komprehensif; dari paradigma menuju aksi. Disampaikan Pada Workshop Penyusunan Program BK Komprehensif Bertempat Di Ruang Sidang Utama Rektorat UNY, Kerjasama Prodi BK UNY Dan PD ABKIN DIY. Yogyakarta: Universitas Negeri Yogyakarta.

Sink, C. A., Cooney, M., \& Adkins, C. (2017). Conducting large-scale evaluation studies to identify characteristics of effective comprehensive school counseling programs. In International handbook for policy research on school-based counseling (pp. 133152). Springer, Cham.

Stone, C., \& Dahir, C. A. (2015). The transformed school counselor. Nelson Education.

Virani, I. A. D., Riastini, P. N., \& Suarjana, I. M. (2016). Deskripsi sikap sosial 
siswa kelas IV SD Negeri 4

penarukan kecamatan buleleng

kabupaten buleleng. MIMBAR PGSD

Undiksha, 4(2). 